\title{
VARIATION IN THE AGE AT FIRST SPAWNING OF FEMALE TWAITE SHAD (ALOSA FALLAX FALLAX) FROM THE RIVER SEVERN, ENGLAND.
}

\author{
M.W. APRAHAMIAN, S.M. LESTER
}

Environment Agency, North West Region, Richard Fairclough House, Knutsford Road, WARRINGTON, WA4 1HG, UK.

\begin{abstract}
The mean age of maturity of female Alosa fallax fallax based on annual samples ranged from 4.28 to 5.26 years, with an overall mean $\pm 95 \% \mathrm{Cl}$ of $4.80 \pm 0.021$ years. The mean age at first spawning was determined for the $1973-1992$ year classes and ranged from 4.41 years to 5.40 years. A significant power relationship existed between the mean age at first spawning and the combined biomass of the $0-2$ and $0-3$ age groups $(P<0.05)$, explaining $40.7 \%$ and $31.6 \%$ of the variability in the age at which a year class matures.

The relationship between maturity and biomass indicates that the onset of maturity was related to density-dependent processes and fish, that matured early had significantly faster growth rates compared to those that matured later $(P<0.05)$.

The findings suggest that the immature fish at sea congregate in a fairly restricted area where it is likely that the older year classes impact younger ones. The fact that the relationship between maturity and the biomass of various components of the stock breaks down after the age of four may relate to the onset of maturity, as the mature fish enter the rivers to spawn and are effectively isolated from the main population.
\end{abstract}

Key-words : age at maturity, growth, Alosa fallax fallax, River Severn.

\section{VARIATION DE L’ÂGE À LA PREMIÈRE PONTE DE LA FEMELLE ALOSE (ALOSA FALLAX FALLAX) DU FLEUVE SEVERN, ANGLETERRE.}

\section{RÉSUMÉ}

L'âge moyen des femelles Alosa fallax fallax à maturité sexuelle provenant d'échantillons annuels s'étale entre 4.86 et 5.26 ans, avec une moyenne $\pm 95 \% \mathrm{Cl}$ de $4.80 \pm 0.021$ années. L'âge moyen à la première ponte fut déterminé pour les classes annuelles 1973-1992 et s'étend entre 4.41 et 5.40 ans. Une relation de type puissance $\left(y=a X^{b}\right)$ entre l'âge moyen à la première ponte et la biomasse combinée des groupes 
d'âge 0-2 et $0-3(P<0.05)$ permet d'expliquer $40.7 \%$ et $31.6 \%$ de la variabilité de la cohorte arrivée à maturité sexuelle.

La relation entre l'âge de la maturité sexuelle et la biomasse indique que le commencement de la maturité est fonction de la densité des poissons. Les poissons qui sont arrivés tôt à maturité ont un taux de croissance plus rapide que ceux arrivés à maturité plus tardivement $(P<0.05)$.

Les résultats suggèrent que les poissons immatures de mer se rassemblent dans une aire assez restreinte où il est probable que les cohortes plus âgées impactent sur les plus jeunes. Le fait que la relation entre l'âge de la maturité sexuelle et la biomasse de plusieurs composantes du stock détériore après l'âge de quatre ans est peut-être dû au fait qu'au commencement de la maturité sexuelle, les poissons matures pénètrent en rivière pour pondre et sont donc isolés de la population principale.

Mots-clés : âge maturité sexuelle, croissance, Alosa fallax fallax, fleuve Severn.

\section{INTRODUCTION}

Fitness, measured in terms of either the number of female offspring produced by a female during her life time or in terms of the instantaneous rate of increase of a genotype, is sensitive to the age at which fish mature (STEARNS, 1992). Both measures of fitness respond similarly to changes in growth and mortality with increasing growth and immature mortality resulting in a decrease in the age fish mature (ROFF, 1992). The instantaneous rate of increase is also dependent on early larval survival, the difference in mortality rate pre and post maturation, their ultimate size and in the relationship between fecundity and size (ROFF, 1992).

Female Alosa fallax fallax (Lacépède, 1803) mature at between 3 and 8 years old with the majority maturing at age 4 and 5 years at the northern limit of their distribution and at age 4 years for more southerly populations (DOUCHEMENT, 1981 ; APRAHAMIAN, 1982 ; MENNESSON-BOISNEAU and BIOSNEAU, 1990 ; O'MAOILEIDIGH, 1990 ; TAVERNY, 1991 ; SABATIÉ, 1993), there have been no investigations into inter or intrapopulation differences.

Except for the studies on American shad, Alosa sapidissima (Wilson), by LEGGETT (1969), CARSCADDEN and LEGGETT (1975), LEGGETT and CARSCADDEN (1978) and by SHOUBRIDGE and LEGGETT (1978) the factors affecting life history differences both within and between populations of Alosa have been little investigated. Such comparisons of life history traits are dependent on measuring the variation in individual traits and if possible understanding the variability. The aim of this study was to investigate variation in the age at maturity in Alosa fallax fallax from the River Severn and to try and identify causal factors.

\section{MATERIAL AND METHODS}

The age at first spawning was determined from scales (BAGLINIÈRE et al., 2001) from adult fish caught in the Severn Estuary near Lydney (National Grid Reference ST611991) between 1979 and 1998 at the start of the freshwater phase of their spawning migration. No sample was taken in 1982. As a result the age at maturity for the 1976 year class was calculated from seven year old fish caught in 1983. 
Growth rate was calculated using scales from fish spawning for the first time according to the scale proportional hypothesis (FRANCIS, 1990). Sample sizes ranged from 6 to 30 fish. When $<30$ fish were caught, the entire sample was used and when $>30$ were caught, a sample of 30 fish was chosen using random numbers. For each fish, mean length (fork) at age was back-calculated from five scales.

An index of stock size was calculated from year class strength assuming a constant annual survival rate. Year class strength was determined as described by APRAHAMIAN and APRAHAMIAN (2001). Annual survival rate was taken from the relationship between the number of 6 year old female shad caught in year $n$ and the number of 7 year olds caught in year $n+1$ (Figure 1). An index of total biomass was estimated using mean weight at age (Table 1) and assuming a $50: 50$ sex ratio (APRAHAMIAN, 1982). The index of stock size was calculated separately for the 0 age group and the $0-1$ to $0-5$ age groups inclusive as follows :

$$
\mathrm{B}_{\mathrm{i}}=\sum_{\mathrm{a}=1-1}^{n} \mathrm{Y}_{\mathrm{i}} \mathrm{S}^{\mathrm{a}-1} \mathrm{~W}_{\mathrm{a}}
$$

Where :

$$
\begin{aligned}
& \mathrm{i}=\text { year } \\
& \mathrm{a}=\text { age } \\
& \mathrm{B}_{\mathrm{i}}=\text { Biomass index for year } \mathrm{i} \\
& \mathrm{S}=\text { Survival rate (constant) } \\
& \mathrm{W}_{\mathrm{a}}=\text { mean weight at age } \mathrm{a}(1 \leq \mathrm{a} \leq 5)
\end{aligned}
$$

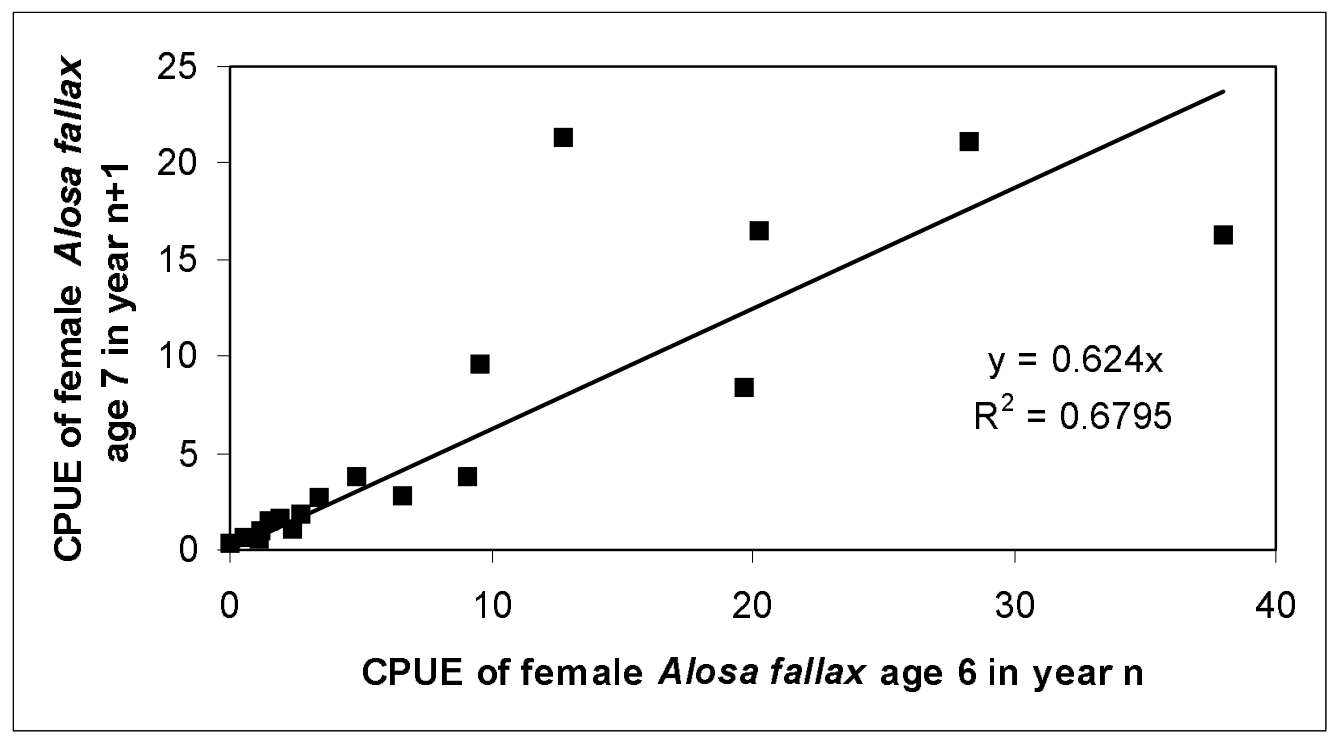

Figure 1

Relationship between the number of seven year old repeat spawning female Alosa fallax caught in year $n+1$ and the number of six year olds caught in year $n$.

\section{Figure 1}

Relation entre le nombre de femelles Alosa fallax de sept ans pondant à répétition, capturées à l'année $n+1$, et le nombre des six ans capturées à l'année $\mathbf{n}$. 


\section{Table I}

Mean weight (g) of male and female Alosa fallax at age 1-9 from the River Severn.

\section{Tableau I}

Poids moyen du mâle et de la femelle Alosa fallax âgés de 1 à 9 ans du fleuve Severn.

\begin{tabular}{|c|c|c|c|c|c|c|c|c|c|c|}
\hline \multirow{2}{*}{ Sex } & \multicolumn{7}{|c|}{ Age (year) } & \multirow{2}{*}{ Reference } \\
\cline { 2 - 10 } & 1 & 2 & 3 & 4 & 5 & 6 & 7 & 8 & 9 & \\
\hline$M$ & 4.8 & 50.0 & 176.8 & 321.6 & 399.9 & 461.0 & 530.8 & 529.8 & 569.6 & APRAHAMIAN \\
$\mathrm{F}$ & 6.1 & 63.3 & 220.2 & 430.4 & 593.6 & 713.3 & 770.7 & 839.5 & 950.2 & $(1982)$ \\
\hline
\end{tabular}

\section{RESULTS}

Age at maturity was determined from 5090 scales collected between 1979 and 1998 from fish aged between 3 and 12 years old. Female Alosa fallax fallax from the River Severn matured between 3 and 8 years old with the majority maturing at age $5,<2 \%$ matured after the age of 6 , with a mean $\pm 95 \% \mathrm{Cl}$ of $4.80 \pm 0.021$ years (Table II). The mean age at maturity for the various sample years between 1979 and 1998 , with the exception of 1982, ranged from 4.28 (1993) to 5.26 (1983) years with a mean $\pm 95 \% \mathrm{Cl}$ of $4.78 \pm 0.15$, sample sizes ranged from 85 to 506 (Figure 2).

The proportion of fish maturing at different ages and the mean age at maturation for the 1973-1992 cohorts was determined from fish age 6 . The mean age at first spawning ranged from 4.41 years (1981) to 5.40 years (1986). However, for some year classes, in particular those of 1980, $1987 \& 1988$, the number of fish aged was small $(<10)$ (Table III). Of the 17 year classes where a reasonable number of fish were aged $(\geq 10)$, the majority (9) of the age classes matured at age $5(52.9 \%)$; four matured at age $4(23.5 \%)$ and one at age $6(5.9 \%)$. Of the three age classes remaining two contained approximately equal numbers maturing at 4 and $5(11.8 \%)$ and one at 5 and $6(5.9 \%)$.

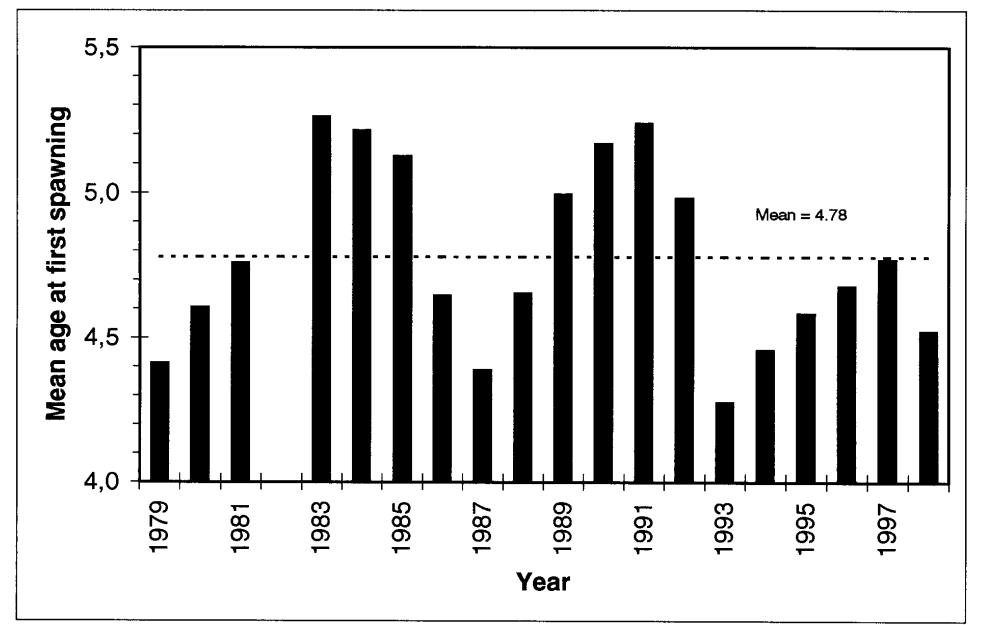

Figure 2

The mean age (year) at maturity for female Alosa fallax sampled between 1979 and 1998, no sample was taken in 1982.

\section{Figure 2}

L'âge moyen (année) à maturité sexuelle des femelles échantillonnées entre 1979 et 1998, aucun échantillon pris en 1982. 
Table II

Age at first spawning of female Alosa fallax from the River Severn $(n=5090)$.

Tableau II

Age de la femelle Alosa fallax à la première ponte du fleuve Severn $(n=5090)$.

\begin{tabular}{|c|c|}
\hline Age at maturity & Percent \\
\hline 3 & 2.16 \\
\hline 4 & 33.16 \\
\hline 5 & 48.80 \\
\hline 6 & 14.54 \\
\hline 7 & 1.26 \\
\hline 8 & 0.08 \\
\hline
\end{tabular}

Table III

The mean age and the percentage of female twaite shad spawning for the first time at various ages for the 1973-1992 year classes.

Tableau III

L'âge moyen de la femelle alose feinte et le pourcentage de la première ponte pour plusieurs âges pour les cohortes 1973-1992.

\begin{tabular}{|c|c|c|c|c|c|c|}
\hline \multirow{2}{*}{$\begin{array}{l}\text { Year } \\
\text { class }\end{array}$} & \multirow{2}{*}{$\begin{array}{l}\text { No. } \\
\text { aged }\end{array}$} & \multicolumn{4}{|c|}{ Age at maturity } & \multirow{2}{*}{$\begin{array}{l}\text { Mean Age } \\
\pm 95 \% \mathrm{Cl}\end{array}$} \\
\hline & & 3 & 4 & 5 & 6 & \\
\hline 1973 & 32 & 0.00 & 59.37 & 37.50 & 3.13 & $4.44 \pm 0.204$ \\
\hline 1974 & 29 & 0.00 & 48.27 & 27.59 & 24.14 & $4.76 \pm 0.316$ \\
\hline 1975 & 145 & 2.76 & 42.06 & 46.21 & 8.97 & $4.61 \pm 0.113$ \\
\hline 1976 & 65 & 0.00 & 13.84 & 43.08 & 43.08 & $5.29 \pm 0.174$ \\
\hline 1977 & 36 & 2.78 & 22.22 & 50.00 & 25.00 & $4.97 \pm 0.272$ \\
\hline 1978 & 28 & 0.00 & 3.57 & 78.57 & 17.86 & $5.14 \pm 0.174$ \\
\hline 1979 & 47 & 0.00 & 21.28 & 57.44 & 21.28 & $5.00 \pm 0.194$ \\
\hline 1980 & 9 & 0.00 & 0.00 & 88.89 & 11.11 & $5.11 \pm 0.256$ \\
\hline 1981 & 17 & 0.00 & 58.82 & 41.18 & 0.00 & $4.41 \pm 0.261$ \\
\hline 1982 & 135 & 0.74 & 60.74 & 33.33 & 5.19 & $4.43 \pm 0.103$ \\
\hline 1983 & 252 & 0.79 & 14.29 & 53.17 & 31.75 & $5.16 \pm 0.085$ \\
\hline 1984 & 214 & 0.00 & 6.07 & 58.42 & 35.51 & $5.29 \pm 0.078$ \\
\hline 1985 & 16 & 0.00 & 18.75 & 68.75 & 12.50 & $4.94 \pm 0.305$ \\
\hline 1986 & 10 & 0.00 & 10.00 & 40.00 & 50.00 & $5.40 \pm 0.500$ \\
\hline 1987 & 1 & 0.00 & 0.00 & 100.00 & 0.00 & 5.00 \\
\hline 1988 & 5 & 0.00 & 20.00 & 60.00 & 20.00 & $5.00 \pm 0.878$ \\
\hline 1989 & 232 & 7.33 & 41.81 & 42.24 & 8.62 & $4.52 \pm 0.098$ \\
\hline 1990 & 87 & 1.15 & 27.59 & 62.06 & 9.20 & $4.79 \pm 0.131$ \\
\hline 1991 & 23 & 0.00 & 8.70 & 82.60 & 8.70 & $5.00 \pm 0.184$ \\
\hline 1992 & 39 & 0.00 & 43.59 & 53.85 & 2.56 & $4.59 \pm 0.178$ \\
\hline
\end{tabular}


The general trend over the period was for a gradual increase in the age at first spawning from the 1973 through to the 1976 year classes, after which it leveled off before declining to approximately 4.4 years for the 1981 and 1982 year classes. Age at maturity then increased again to approximately 5 years following which it again declined to less than 5 years for the 1989 to 1992 year classes, with the exception of the 1991 year class.

The growth rate, of fish maturing at different ages, from four year classes where reasonable sample sizes were available (1982, 1983, 1984 and 1989) is shown in Figure 3. Estimates of length at age were only made from fish spawning for the first time, because of the erosion of scale material associated with spawning; as such Figure 3 depicts growth rate prior to maturation. All four year-classes showed a similar trend, the faster growing fish maturing earliest, and maturation being associated with the fish reaching a size (fork length) of between 31.4 and $35.5 \mathrm{~cm}$ (median $=33.65 \mathrm{~cm}$ ). However, the six year old fish from all four cohorts were estimated to have a mean length of between 31.5 and $32.5 \mathrm{~cm}$ at age 5. Though larger in size than the smallest group which had matured (31.4 $\pm 0.9 \mathrm{~cm} ; 1989$ year-class maturing at age 3$)$ they were in the lower size quartile $(<32.6 \mathrm{~cm})$ when compared with those which had matured at age 5 (Table IV). The difference in growth rate was evident at an early age (Table IV) with fish of $12 \mathrm{~cm}$ at age 1 maturing at age 3 ; between 7.6 and $9.2 \mathrm{~cm}$ maturing at age 4 ; between 6.6 and $7.7 \mathrm{~cm}$ at age 5 and between 6.1 and $7.2 \mathrm{~cm}$ at age 6 . For fish maturing at ages 5 and 6 years old there was some overlap in the length at age between the two groups until the age of 4 with those maturing at age 5 being on average $\geq 28.5 \mathrm{~cm}$ while those maturing at age 6 years were $<28.5 \mathrm{~cm}$.

\section{Table IV}

Mean fork length $\pm 95 \% \mathrm{Cl}(\mathrm{cm})$ at age of four year-classes of female Alosa fallax prior to maturation.

\section{Tableau IV \\ Moyenne de la longueur de la fourche $\pm 95 \% \mathrm{Cl}(\mathrm{cm})$ à l'âge de la femelle Alosa fallax des quatre cohortes avant leurs maturation.}

\begin{tabular}{|c|c|c|c|c|c|c|c|c|}
\hline \multirow{2}{*}{$\begin{array}{c}\text { Age at } \\
\text { Maturity }\end{array}$} & Year & \multicolumn{9}{|c|}{ Age (year) } & \multicolumn{2}{c|}{$\begin{array}{c}\text { Sample } \\
\text { size }\end{array}$} \\
\hline & Class & 1 & 2 & 3 & 4 & 5 & 6 & 11 \\
\hline 3 & 1989 & $12.0 \pm 0.98$ & $23.5 \pm 1.0$ & $31.4 \pm 0.90$ & & & & 30 \\
\hline 4 & 1982 & $7.6 \pm 0.50$ & $19.3 \pm 0.59$ & $27.1 \pm 0.55$ & $33.0 \pm 0.45$ & & & 29 \\
& 1983 & $9.2 \pm 0.44$ & $18.8 \pm 0.54$ & $26.7 \pm 0.66$ & $32.1 \pm 0.63$ & & & 30 \\
\hline & 1989 & $8.0 \pm 0.67$ & $19.4 \pm 1.03$ & $27.2 \pm 1.10$ & $32.7 \pm 1.08$ & & & 28 \\
& 1982 & $6.6 \pm 0.42$ & $17.2 \pm 0.61$ & $24.4 \pm 0.56$ & $30.4 \pm 0.56$ & $34.1 \pm 0.55$ & & 30 \\
& 1983 & $7.5 \pm 0.37$ & $16.1 \pm 0.72$ & $23.3 \pm 0.81$ & $29.0 \pm 0.68$ & $33.4 \pm 0.60$ & & 27 \\
& 1984 & $7.7 \pm 0.40$ & $14.9 \pm 0.83$ & $22.4 \pm 0.83$ & $28.5 \pm 0.74$ & $33.2 \pm 0.51$ & & 30 \\
\hline 6 & 1989 & $6.9 \pm 0.39$ & $15.8 \pm 0.84$ & $23.4 \pm 0.74$ & $29.8 \pm 0.51$ & $34.7 \pm 0.46$ & & 6 \\
& 1982 & $6.6 \pm 0.67$ & $15.6 \pm 0.75$ & $22.7 \pm 0.66$ & $28.4 \pm 0.82$ & $32.0 \pm 1.14$ & $34.8 \pm 1.45$ & 6.59 \\
& 1983 & $7.2 \pm 0.41$ & $15.0 \pm 0.73$ & $22.1 \pm 0.87$ & $27.8 \pm 0.81$ & $32.5 \pm 0.78$ & $35.5 \pm 0.59$ & 28 \\
& 1984 & $7.2 \pm 0.34$ & $13.8 \pm 0.68$ & $20.5 \pm 0.66$ & $26.6 \pm 0.61$ & $31.5 \pm 0.59$ & $35.4 \pm 0.55$ & 29 \\
& 1989 & $6.1 \pm 0.38$ & $13.4 \pm 1.02$ & $20.5 \pm 1.06$ & $26.8 \pm 0.97$ & $31.7 \pm 1.02$ & $34.8 \pm 0.88$ & 20 \\
\hline
\end{tabular}



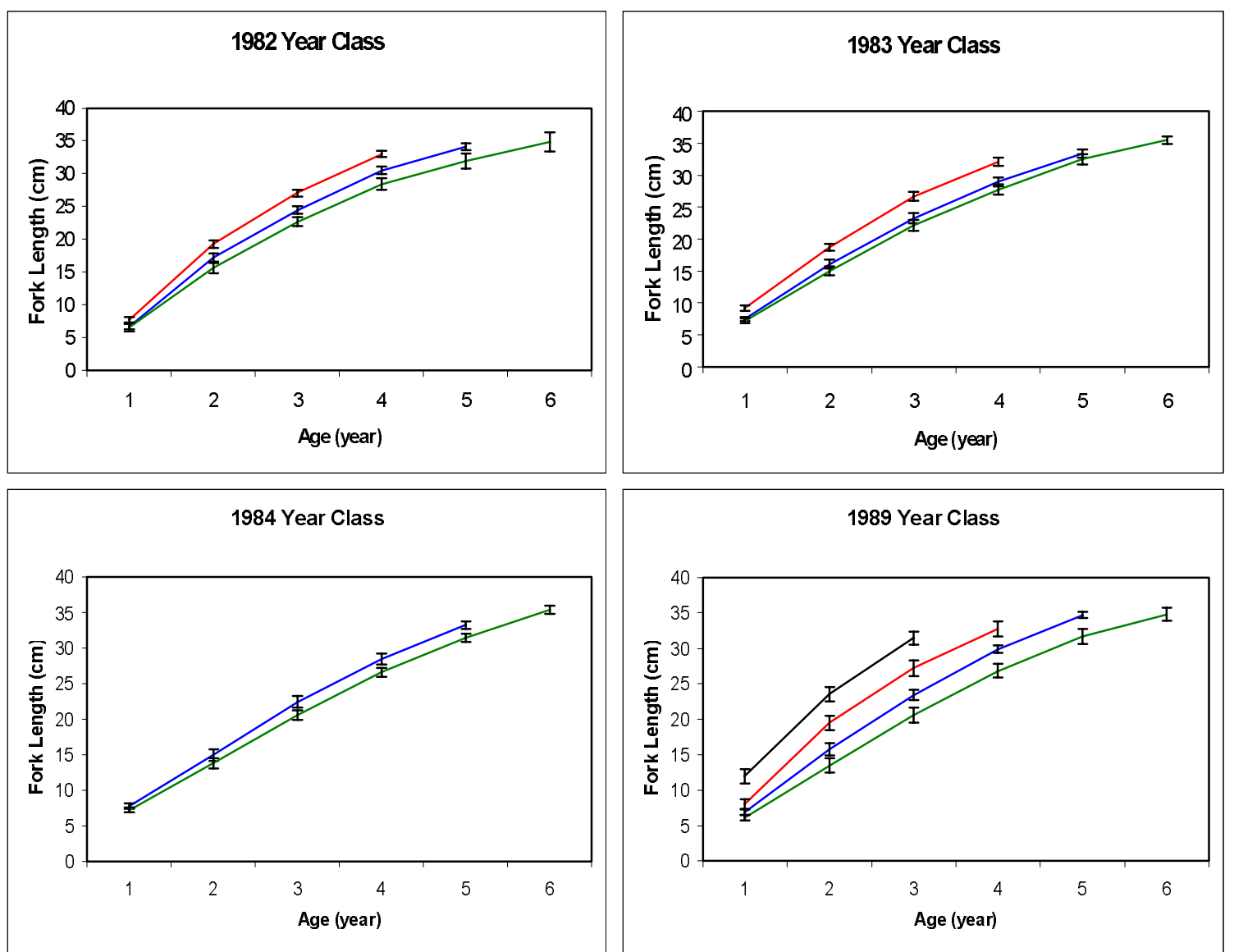

\section{Figure 3}

Growth rate (mean fork length $\pm 95 \% \mathrm{Cl}$ ) of four year-classes of female Alosa fallax maturing at between 3 and 6 years old.

\section{Figure 3}

Taux de croissance des femelles Alosa fallax (la moyenne de la longueur de la fourche $\pm 95 \% \mathrm{Cl}$ ) des quatre cohortes qui arrivent à la maturité entre les âges de 3 à 6 ans.

The relationship between the mean age at which fish from a particular year class matured and an index of the size of various components of the population is presented in Figure 4. There was no significant $(P>0.05)$ relationship between age at maturity of a year-class and its abundance $\left(r^{2}=0.0007\right)$ or the combined biomass of the one year old fish $\left(r^{2}=0.198\right)$. A significant $(P<0.05)$ power relationship did exist between age at maturity and the combined biomass of the 0 to $2\left(r^{2}=0.407\right)$ and 0 to $3\left(r^{2}=0.316\right)$ age groups. The inclusion of the older age groups (ages four and five) did not produce a significant relationship $\left(r^{2}=0.254\right.$ and 0.098 , respectively). The relationship indicates that at low population levels the fish mature early, maturing later with increasing size of the stock up to an asymptote of about 5 years. 


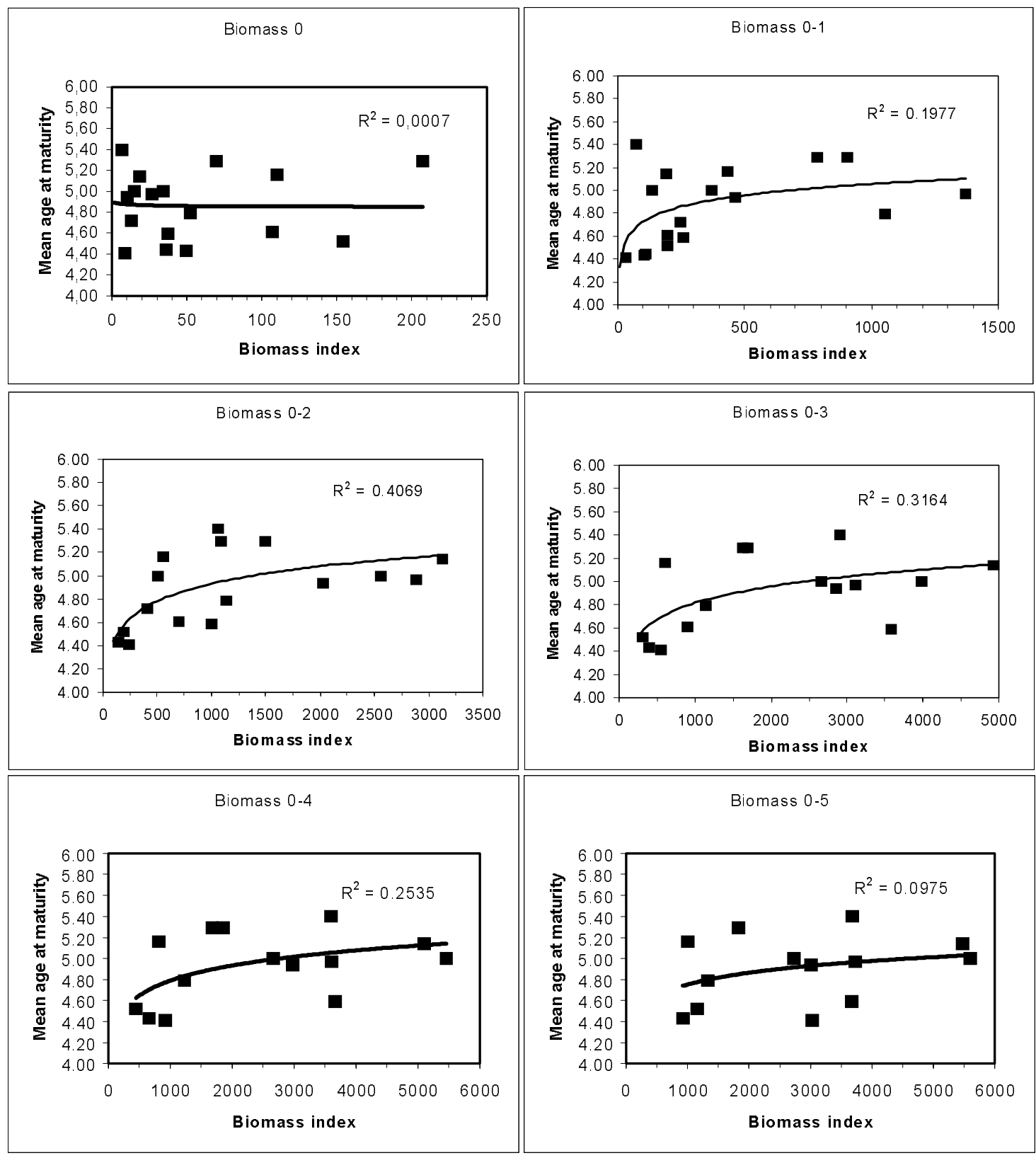

Figure 4

The relationship between age at maturity for female Alosa fallax and an index of biomass for age group 0 to $0-5$ inclusive, only those year-classes where more than $\mathbf{1 0}$ fish were sampled have been included.

Figure 4

La relation entre l'âge de la femelle Alosa fallax à maturité sexuelle et un index de biomasse pour les groupes d'âges 0 et 0-5 y compris, incluant seulement les cohortes où plus de 10 poissons furent récoltés. 


\section{DISCUSSION}

The mean age at first spawning in the River Severn (4.8 years) is greater than that of other populations (Table V). Comparisons between these rivers need to be made with caution as most of the studies with the exception of TAVERNY (1991), SABATIÉ (1993) and the present study were based on one year's sample and small sample sizes. In addition, studies from the Severn indicate that the mean age at maturity can vary by up to a year. This level of intra-population variation is greater than that reported by LEGGETT (1969) for Alosa sapidissima of 0.2 years in $70 \%$ of cases, but could be as high as 0.5 years. However, the fact that the mean age at maturity in some other populations is close to or less than the lowest age at maturity observed in the Severn suggests that the age at which Alosa fallax mature varies significantly between populations. LEGGETT and CARSCADDEN (1978) reported significant differences for Alosa sapidissima in the age at maturity between populations but no latitudinal trend along the Atlantic coast of North America. However, the mean size at age increased with increasing latitude. In contrast, SABATIÉ et al. (1996) found no significant difference in the age at maturity for Alosa alosa from the rivers Lima (Portugal) and Sebou (Morocco).

\section{Table V}

Percentage of female Alosa fallax maturing at different ages from various river systems.

\section{Tableau V}

Pourcentage des femelles Alosa fallax qui arrivent à maturité sexuelle à différents âges provenant de systèmes riverains divers.

\begin{tabular}{|c|c|c|c|c|c|c|c|c|c|}
\hline \multirow[t]{2}{*}{ River } & \multicolumn{6}{|c|}{ Age (years) } & \multirow{2}{*}{$\begin{array}{c}\text { Mean } \\
\pm 95 \% \mathrm{Cl}\end{array}$} & \multirow[t]{2}{*}{ No. } & \multirow[t]{2}{*}{ Reference } \\
\hline & 3 & 4 & 5 & 6 & 7 & 8 & & & \\
\hline $\begin{array}{c}\text { Wye } \\
\text { (Wales) }\end{array}$ & & 46.6 & 51.4 & 2.0 & & & $\begin{array}{r}4.55 \\
\pm 0.09 \\
\end{array}$ & 148 & $\begin{array}{l}\text { APRAHAMIAN } \\
\text { (1982 \& unpubl.) }\end{array}$ \\
\hline $\begin{array}{l}\text { Severn } \\
\text { (England) }\end{array}$ & 2.2 & 33.2 & 48.8 & 14.5 & 1.3 & 0.1 & $\begin{array}{r}4.80 \\
\pm 0.02 \\
\end{array}$ & 5090 & This study \\
\hline $\begin{array}{l}\text { Barrow } \\
\text { (Ireland) }\end{array}$ & 4.8 & 57.1 & 33.3 & 4.8 & & & $\begin{array}{r}4.38 \\
\pm 0.31 \\
\end{array}$ & 21 & $\begin{array}{c}\text { O'MAOILEIDIGH } \\
(1990)\end{array}$ \\
\hline (Holland) & 19.5 & 67.5 & 13.0 & & & & $\begin{array}{r}3.94 \\
\pm 0.13 \\
\end{array}$ & 77 & $\begin{array}{c}\text { APRAHAMIAN } \\
(1982) \\
\end{array}$ \\
\hline $\begin{array}{c}\text { Loire } \\
\text { (France) }\end{array}$ & 8.3 & 65.0 & 18.4 & 8.3 & & & $\begin{array}{r}4.27 \\
\pm 0.20 \\
3.55 \\
\pm 0.20 \\
\end{array}$ & $\begin{array}{l}56 \\
34\end{array}$ & $\begin{array}{c}\text { DOUCHEMENT } \\
(1981) \\
\text { MENNESSON-BOISNEAU and } \\
\text { BIOSNEAU }(1990)\end{array}$ \\
\hline $\begin{array}{l}\text { Charente } \\
\text { (France) }\end{array}$ & 17.9 & 71.4 & 10.7 & & & & $\begin{array}{r}3.93 \\
\pm 0.21 \\
\end{array}$ & 28 & VERON (unpubl.) \\
\hline $\begin{array}{l}\text { Gironde- } \\
\text { Garonne- } \\
\text { Dordogne } \\
\text { (France) }\end{array}$ & $\begin{array}{l}11.1 \\
37.1\end{array}$ & $\begin{array}{l}51.1 \\
51.7\end{array}$ & $\begin{array}{l}37.8 \\
11.2\end{array}$ & & & & $\begin{array}{r}4.27 \\
\pm 0.20 \\
3.74 \\
\pm 0.14 \\
\end{array}$ & $\begin{array}{l}45 \\
89\end{array}$ & $\begin{array}{c}\text { DOUCHEMENT } \\
(1981) \\
\text { TAVERNY (1991) }\end{array}$ \\
\hline $\begin{array}{c}\text { Adour } \\
\text { (France) }\end{array}$ & & 65.2 & 34.8 & & & & $\begin{array}{r}4.35 \\
\pm 0.21 \\
\end{array}$ & 23 & $\begin{array}{c}\text { DOUCHEMENT } \\
(1981)\end{array}$ \\
\hline $\begin{array}{c}\text { Sebou } \\
\text { (Morocco) }\end{array}$ & 5.9 & 40.1 & 35.5 & 18.4 & & & $\begin{array}{r}4.66 \\
\pm 0.14 \\
\end{array}$ & 152 & SABATIÉ (1993) \\
\hline
\end{tabular}

The between year variation in age at first spawning results from differences in the age a particular year class matures and from the strength of that year class. The relationship between mean age at maturity of a particular year class and the size of the population suggests that age at maturity is partly under the control of density dependent factors. It would appear that the age at which a year class matures is regulated by the immature population as a whole and not confined to just the size of a particular cohort. If the older year classes are to impact on the younger ones the immature fish must congregate in a fairly restricted area when at sea. In addition, the fact that the relationship breaks down after the age of four may relate to the onset of maturity. On maturation adults 
enter the rivers to spawn and are effectively isolated from the main population over the period of April through to July. There is little information on their distribution at sea. However, the study of TAVERNY (1991) did show that Alosa fallax from the GirondeGaronne-Dordogne (France) system were confined to a relatively small area close to the mouth of the estuary, with individual cohorts remaining together. This suggests that the Severn population has a center of distribution somewhere in the Irish Sea, a suggestion corroborated by their parasite fauna (KENNEDY, 1981 ; APRAHAMIAN, 1985).

The mechanism regulating the onset of maturity appears to be size and/or growth rate dependent with the requirement that individuals must reach a critical size before they mature. For female Alosa fallax from the Severn, the critical size $\left(\mathrm{L}_{\mathrm{f}}\right)$ appears to be approximately 330 to $340 \mathrm{~mm}$ which is generally obtainable by the age of 5 years irrespective of the size of the population. This critical size is close to that predicted from the relationship between length at first reproduction of clupeoids and their maximum fish length (BEVERTON, 1963) : $32.1 \mathrm{~cm}\left(\mathrm{~L}_{\text {inf }}=42.0 \mathrm{~cm}\right.$; APRAHAMIAN unpubl.). The reaching of a critical size may be correlated with the energy reserves needed for successful reproduction. GLEBE and LEGGETT (1981) showed that the mean size at maturation for both male and female $A$. sapidissima increased with latitude from south to north, and attributed this increase to the increased current velocities in the northern rivers during the upstream migration period. In terms of optimising fitness the relationship between maturity and growth rate, the fact that the faster growing fish mature earlier, is in agreement with the models of ROFF (1984) irrespective of which measure of fitness, life time fecundity or the instantaneous rate of increase, is being maximized.

\section{CONCLUSION}

It is concluded that the variation of approximately 1 year in the age at maturity reflects the response to the natural variation in growth rate resulting from density dependent processes such as intraspecific competition for food.

\section{ACKNOWLEDGEMENTS}

We thank C. APRAHAMIAN, N. MOTT and I. WEST for their very valuable assistance. The project was part funded by the Environment Agency (R\&D Project W2i640). The views expressed in this paper are those of the authors and not necessarily those of the Environment Agency.

\section{BIBLIOGRAPHY}

APRAHAMIAN M.W., 1982. Aspects of the biology of the twaite shad, Alosa fallax fallax (Lacépède) in the rivers Severn and Wye. PhD Thesis, University of Liverpool, England, $381 \mathrm{p}$.

APRAHAMIAN M.W., 1985. The effect of the migration of Alosa fallax fallax (Lacépède) into fresh water, on branchial and gut parasites. Journal of Fish Biology, 27, 521532.

APRAHAMIAN M.W., APRAHAMIAN C.D., 2001. The influence of water temperature and flow on year-class strength of twaite shad (Alosa fallax fallax) from the River Severn, England. Bull. Fr. Pêche Piscic., 362/363, 953-972.

BAGLINIĖRE J.L., SABATIÉ M.R., APRAHAMIAN M.W., ALEXANDRINO P., ASSIS C.A APRAHAMIAN C.D., CASSOU-LEINS J.J., LE CORRE M., MENNESSONBOISNEAU C., MARTIN VANDEMBULCKE D., ROCHARD E., TEIXEIRA C., 2001. Guide pour l'interprétation des écailles et l'estimation de l'âge chez les aloses 
(Alosa spp.) de la façade Atlantique-Est et de la Méditerranée-Ouest. Bull. Fr. Pêche Piscic., 357-360, 485-531.

BEVERTON R. J.H., 1963. Maturation, growth and mortality of clupeid and engraulid stocks in relation to fishing. Rapports et Procès-Verbaux des Réunions. Conseil International pour l'Exploration de la Mer, 154, 44-67.

CARSCADDEN J.E., LEGGETT W.C., 1975. Life history variations in populations of American shad, Alosa sapidissima (Wilson), spawning in tributaries of the St John River, New Brunswick. Journal of Fish Biology, 7, 595-609.

DOUCHEMENT C., 1981. Les aloses des fleuves français, Alosa fallax Lacépède 1803 et Alosa alosa Linné 1758. Biométrie, écobiologie, autonomie des populations. Thèse doctorat $3^{\mathrm{e}}$ cycle. Université des Sciences et Techniques du Languedoc, France, $377 \mathrm{p}$.

FRANCIS R.I.C.C., 1990. Back-calculation of fish length : a critical review. Journal of Fish Biology, 36, 883-902.

GLEBE B.D., LEGGETT W.C., 1981. Latitudinal differences in energy allocation and use during the freshwater migrations of American shad (Alosa sapidissima) and the life history consequences. Canadian Journal of Fish and Aquatic Sciences, 38, 806820.

KENNEDY C.R., 1981. The occurrence of Eubothrium fragile (Cestoda : Pseudophyllidae) in twaite shad, Alosa fallax (Lacépède) in the River Severn. Journal of Fish Biology, 19, 171-177.

LEGGETT W.C., 1969. Studies on the reproductive ecology of the American shad (Alosa sapidissima, Wilson). A comparison of populations from four rivers of the Atlantic seaboard. PhD Thesis, McGill University, Canada.

LEGGETT W.C., CARSCADDEN J.E., 1978. Latitudinal variation in reproductive characteristics of American shad (Alosa sapidissima) : evidence for population specific life history strategies in fish. Journal of the Fisheries Research Board of Canada, 35, 1469-1478.

MENNESSON-BOINEAU C., BOISNEAU P., 1990. Recherches sur les aloses du bassin de la Loire : migration, répartition, reproduction, caractéristiques biologiques et taxonomie dea aloses (Alosa sp.). Thèse doctorat, Universités de Rennes I et de Paris XII Val de Marne, France, $106 \mathrm{p}$.

O'MAOILEIDIGH N.O., 1990. A study of fish populations in the Killarney Lakes. PhD Thesis, National University of Ireland, University college Dublin, Ireland.

ROFF D.A., 1984. The evolution of life history parameters in teleosts. Canadian Journal of Fisheries and Aquatic Sciences, 41, 984-1000.

ROFF D.A., 1992. The Evolution of Life Histories. Chapman and Hall, London, 535 p.

SABATIÉ M.R., 1993. Recherches sur l'écologie et la biologie des aloses an Maroc (Alosa alosa Linné, 1758 et Alosa fallax Lacépède, 1803) : exploitation et taxonomie des populations atlantiques, bioécologie des aloses de l'oued Sebou. Thèse doctorat, Université de Bretagne Occidentale, Brest, France, $326 \mathrm{p}$.

SABATIÉ M.R., ALEXANDRINO P., BAGLINIĖRE J.L., 1996. Comparison des caractéristiques biologiques de la grande alosa (Alosa alosa) dans l'oued Sebou (Façade Nord-Atlantique du Maroc) et dans le Fleuve Lima (Portugal). Cybium, 20 (3), 59-73.

SHOUBRIDGE E.A., LEGGETT W.C., 1978. Occurrence and adaptive significance of distinct reproductive strategies in local populations of American shad (25-73). Final Report Project AFC-10. National Marine Fisheries Service U.S., Conneticut, U.S.A, $74 \mathrm{p}$.

STEARNS S.C., 1992. The Evolution of Life Histories. Oxford University Press, Oxford, $249 \mathrm{p}$.

TAVERNY C., 1991. Contribution à la connaissance de la dynamique des populations d'aloses (Alosa alosa et Alosa fallax) dans le système fluvio-estuarien de la Gironde. Pêche, biologie, écologie des aloses dans le système Gironde-GaronneDordogne. Étude particulière de la dévalaison et de l'impact des activités humaines. Thèse Doctorat, Université de Bordeaux, Cemagref div. ALA, 375 p. 
